Grade 12 English teachers' questioning in developing students' critical thinking skills: A two-phase model

Gacutan, Sarah Angela B. $\triangle \backslash$
Laguna College of Business and Arts, Philippines (sbgacutan@gmail.com)

Recillo, Maria Luisa B.

City College of Calamba, Philippines (mlbrecillo@gmail.com)

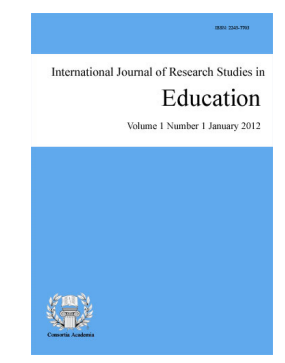

ISSN: 2243-7703 Online ISSN: 2243-7711

OPEN ACCESS

\title{
Abstract
}

The study aimed to determine the level of grade 12 English teachers' questioning in developing students' critical thinking skills. This study used the mixed method research design, specifically explanatory sequential triangulation to determine the level of teachers' questioning using a self-constructed questionnaire answered both by teachers and their subject coordinator, and the critical thinking of students through an assessment test anchored to their English subjects in Senior High School. The mean was used to determine the level of questioning of teachers, while the frequency was used for the critical thinking skills level of students. T-test was then used to compute for the significant difference of the assessment of the English teachers from the subject coordinator. Finally, the Pearson's R Correlation was used to determine the significant relationship of teachers' level of questioning and students' level of critical thinking skills. The findings were as follows: the level of questioning of teachers was very high, while the level of critical thinking skills of students did not meet expectations. On the assessment of the subject coordinator and English teachers on the level of questioning, there is no significant difference between the two groups, but in terms of asking questions, there is a significant difference between the assessment of the two groups. Furthermore, there is no significant relationship between the teachers' level of questioning and students' level of critical thinking skills. With this, this study proposed a work plan entitled Classroom Q and A: Levelling Up of Students' Critical Thinking and Teachers' Questioning.

Keywords: critical thinking, teachers' questioning, comprehension, art of questioning, Bloom's taxonomy 


\section{Grade 12 English teachers' questioning in developing students' critical thinking skills: A two-phase model}

\section{Introduction}

Ever since the creation of the Socratic Method in 469 to 399 B.C., questioning skills in education has always been a required competency of teachers in order to elicit classroom engagement, assessment, feedback, and of top of it is critical thinking skills of the students. The study of Nappi (2018), affirms the relationship of questioning and thinking. This fosters the kind of engagement that the students need. Rigorous planning and implementation are needed for such questions to be deployed inside the classroom. Higher order level of questions can allow students to make connections with previous lessons and make meanings of the world around them. At the same time, there is a deteriorating to stagnant level of critical thinking skills among students across the schools worldwide especially for those that are unsupervised and rarely recalibrate the teachers' skill in questioning. Furthermore, Marques (2017) alarmingly discuss on the national state in the education sector of the Philippines, critical thinking skills can be established if the teachers are doing reflective teaching. In this type of teaching, teachers use prompting questions for students to ponder and think comprehensively and critically; but it is sometimes a didactic approach.

With this, the researcher aimed to identify the level of questioning of teachers in developing critical thinking skills among Grade 12 students at Canossa School, Santa Rosa City, Laguna in their 21st Century Literature from the Philippines and the World, Creative Writing, Qualitative Research, Quantitative Research, and Research Capstone subjects. With this, the study's objectives were to determine the level of critical thinking skills of the respondents, establish teachers' level of questioning in the cognitive process through an assessment from the head teacher and the subject teacher itself, determine the difference in the assessment of the two groups, determine the effects of the teachers' level of questioning on students' critical thinking skills, and develop a plan to improve teachers' questioning and students' critical thinking skills, and by extension, address any difficulties that may arise. The researcher's personal experience bolstered the truth of the matter. During the recent visit of the Philippine Accrediting Association Schools, Colleges and Universities (PAASCU) to Canossa School Santa Rosa where the researcher has been teaching for nearly three years, the members of the group found that the construction of questions given by the teachers in a frontal discussion during classroom observations were significantly low and rarely transpired; hence, critical thinking has not been established. By extension, even in test question construction, PAASCU highlighted that planning and development should be considered to achieve the required types of questioning. Apart from this, in an attempt to answer the recommendations of the association, interested teachers joined the Massive Open Online Course, taking specifically the Integrating Critical Thinking Skills into the Exploration of Culture in an English as a First Language Setting MOOC Survey. It is an online training for teachers who go through different classes in which they will be developing the said skills while exposed to different scenarios uncommon to what they experience inside the school. Besides these measures, the researcher believed that there is still an utmost need to continue creating new opportunities for the enhancement of this skill, not just for the students but also for the teachers as well.

\subsection{Theoretical Framework}

This study was anchored on Glaser and Watson's (1941, as cited in Zulmaulida, Wahyudin, and Afganhi Dahlan, 2018) Development of Critical Thinking Ability, in which they define critical thinking “... an attitude of being disposed to consider in a thoughtful way the problems and subjects that come within the range of one's experiences, knowledge of the methods of logical inquiry and reasoning, and some skills in applying those methods..." This is the ability to further examine ideas presented despite evidence to support it. It also includes the ability to recognize problems and find best solutions, gather relevant information, recognize unstated 
assumptions, comprehend, and use language with accuracy, clarity and discrimination to interpret data, appraise the evidence and evaluate arguments. It also includes drawing warrant conclusions and generalizations, to test the conclusions and generalizations at which one arrives and reconstruct one's patterns of belief on the basis of wider experience and to render accurate judgements about specific things and qualities in everyday life. This theory is most relevant to the research for it expresses a thorough discussion of what encompasses the critical thinking ability which is a primary variable to the research. To Watson and Glaser, the critical thinking of students can be identified through these levels: Evaluating assumptions, Recognizing assumptions, Analyzing arguments, Deduction, Drawing inferences, and Drawing information. These levels were the basis for measuring the level of questioning of the teachers to Very High, High, Low, and Very low.

Other than this is the Bloom's (1956) Taxonomy, specifically in the cognitive process. Benjamin Bloom is the proponent of the widely used taxonomy guide in education to promote higher forms of thinking such as analyzing concepts and evaluating concepts, process, procedures, and principles rather than just relying on rote learning. Other than the cognitive domain, it is also followed by the affective and psychomotor domain. Furthermore, the revised taxonomy by Anderson and Krathwohl (2000) was the basis for measuring the critical thinking ability of the students. The levels are as follows: Remembering, Understanding, Applying, Analyzing, Evaluating, and Creating.

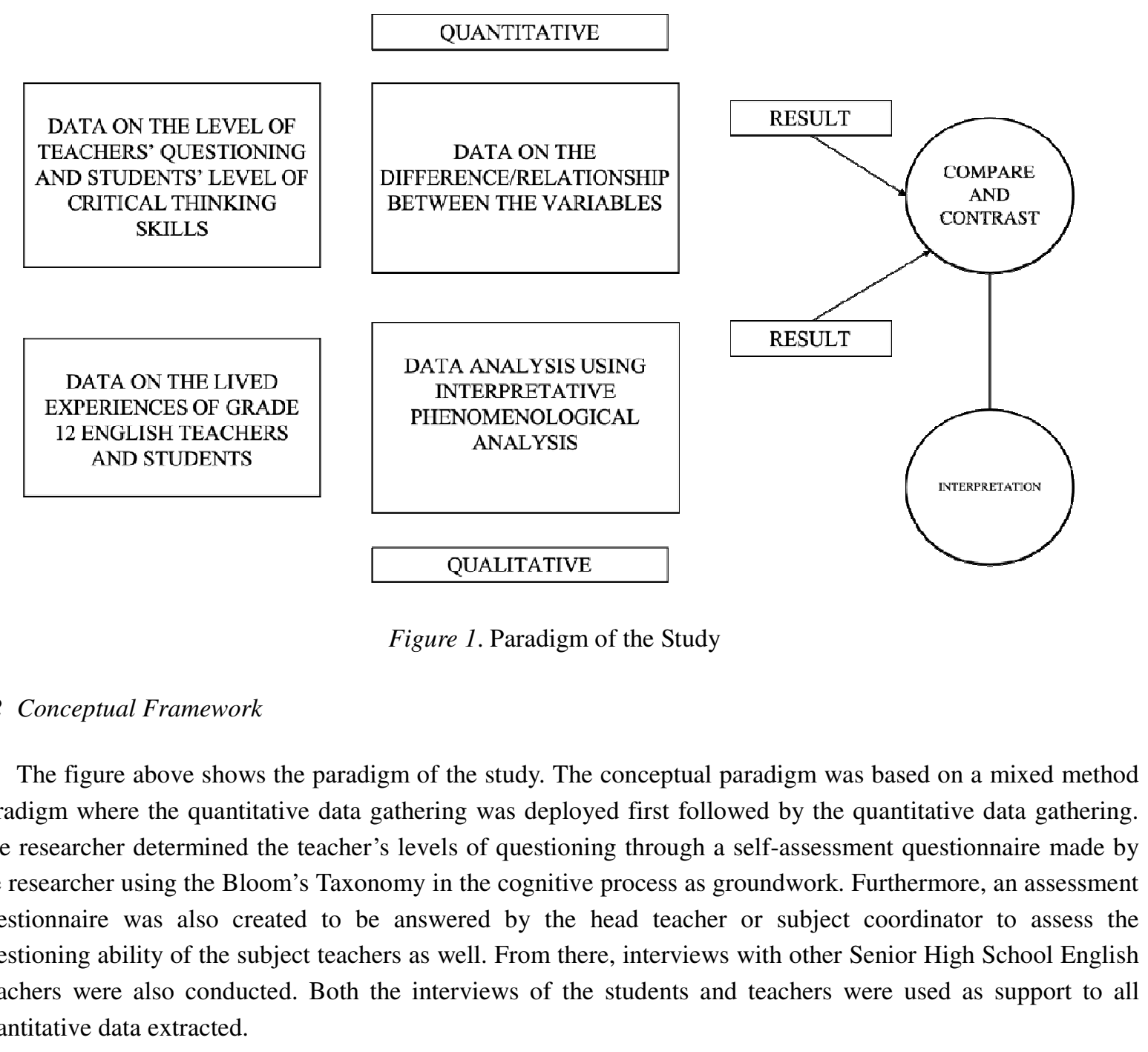

Next, the researcher determined the level of critical thinking skills of Grade 12 students of Canossa School, Santa Rosa through a Critical Thinking test adopted from the Watson-Glaser Critical Thinking Ability Level 
Gacutan, S. A. B., \& Recillo, M. L. B.

RED Model, and the scope of topics is from the given handouts to the students by their Subject Teachers and from their textbook or handouts in 21st Century Literature from the Philippines and the World, Creative Writing, Qualitative Research, Quantitative Research, and Research Capstone. Then, an interview with the students was also conducted to get the emerging themes regarding their level of critical thinking.

Presented next is the transcription of the interviews conducted. Then this was followed by the analysis of data gathered from the tests collated from the participants. Lastly, a correlation analysis and comparative analysis were done to determine the effect of the teachers' frequency of using different types of questions to the level of critical thinking skills among Grade 12 students. The expected output for this research would have been an assessed level of students' critical thinking skills and assessed frequency of teachers' use of different levels of questions which then became a basis for the improvement of the said variables. Furthermore, a developed work plan entitled" Classroom Q and A: Leveling up of Students' Critical Thinking and Teachers' Questioning," would be accomplished as a product of this research.

\subsection{Statement of the Problem}

The main objective of this study was to determine the level of questioning of teachers in developing the critical thinking skills among Grade 12 Students of Canossa School, Santa Rosa City, Laguna.

Specifically, it sought answers to the following problems:

1. What is the level of teachers' questioning in terms of remembering, understanding, applying, analyzing, evaluating, and creating?

2. What is the level of critical thinking skills among Grade 12 Senior High School Students in terms of evaluating assumptions, recognizing assumptions, analyzing arguments, deduction, drawing information, and drawing inferences?

3. Is there a significant difference in the assessment of the subject teachers and subject coordinator based on the levels of teachers' questioning in terms of remembering, understanding, applying, analyzing, evaluating, and Creating?

4. Is there a significant relationship between the teachers' level of questioning and students' level of critical thinking skill?

5. Based on the findings of the study, what enhancement program may be proposed to improve teachers' level of questioning and the level of students' critical thinking skills?

6. What is the essence of the lived experiences of the teachers in asking questions and the students' level of critical thinking in answering them in a classroom setting?

\subsection{Hypothesis}

The following hypotheses were tested for their significance:

$>$ There is no significant difference in the assessment of the subject teachers and subject coordinator based on the levels of teachers' questioning.

$>$ There is no significant relationship between the teachers' level of questioning and the students' level of critical thinking skills.

\subsection{Scope and Delimitations}

This study focused on the teachers' level of questioning in developing the critical thinking skills among

90 Consortia Academia Publishing (A partner of Network of Professional Researchers and Educators) 
Grade 12 Students of Canossa School, Santa Rosa. It measured the critical thinking skills of the respondents through the Critical Thinking Test created by the researcher focusing mainly on the sub-skills of the Critical Thinking which was measured through a multiple-choice test rooted in the First Quarter Lessons of their subject in 21st Century Literature from the Philippines and the World, Creative Writing, Qualitative Research, Quantitative Research, and Research Capstone. A self-assessment answered by the subject teacher and a teacher-assessment answered by the head teacher or subject coordinator were created to measure the frequency of the teachers' questioning in the cognitive process.

The Grade 12 students were chosen since they were the closest to exiting the senior high school level and in entering the collegiate level in education which further strengthened the need to evaluate and determine their critical thinking ability. These students by now, should just be enhancing this ability and are already competent.

\section{Materials and Methods}

\subsection{Research Design}

Employing a mixed method and the explanatory sequential triangulation, this study tried to determine the teachers' level of questioning in developing the critical thinking skills among Grade 12 students. To Burke, Onwuegbuzie, and Turner (2007, as cited in Schoonenboom and Johnson, 2017), the idea of triangulation, referring to "multiple operationalism," is one in which more than one method is used as part of a validation process that ensures that the explained variance is the result of the underlying phenomenon or trait and not of the method, quantitative or qualitative.

From Leech (2008), he defined the mixed method in general as the involvement of collecting, analyzing, and interpreting quantitative and qualitative data in a single study or series of studies that investigate the same underlying phenomena. Furthermore, according to Creswell and Clark (2007), it is a research design with philosophical assumptions that guide the direction of the collection and analysis of data and the mixture of qualitative and quantitative data; while to Burke, Onwuegbuzie, and Turner (2007), the explanatory sequential triangulation is utilized when the results of one approach are necessary for planning the next method.

\subsection{Research Instrument}

The researcher created a critical thinking assessment test patterned from the Watson-Glaser Critical Thinking Assessment Test. It aims to measure the level of critical thinking of the students in terms of evaluating assumptions, recognizing assumptions, analyzing arguments, deduction, drawing information, and drawing inference. The content of the test came from textbooks and hand-outs of their English subjects: Qualitative Research, Quantitative Research, Research Capstone, Creative Writing, and 21st Century Literature. Since not all strands take all subjects generally, the test was designed without needing any prior knowledge of that subject. The test consists of thirty (30) items where there are five (5) items for each level while six (6) items were allocated to cover all mentioned subjects.

The second instrument was the teachers' self-assessment which aimed to measure their level of questioning during classes. It consists of thirty (30) items. This was anchored to Bloom's Taxonomy in the Cognitive Process which presents the six levels of questioning. Five (5) items were equally designated to these levels. This was given to the five (5) Grade 12 English Teachers. The same test was given to the subject area coordinator or head teacher to assess these teachers' level of questioning.

Finally, an interview was conducted with five (5) Grade 12 students from different strands and the five (5) Grade 12 English teachers to add more validity to the results provided by the quantitative part of the study which removed whatever biases that were found in the numerical results so as to come up with the truth about the topic under the study. 


\subsection{Respondents of the Study}

Through the stratified proportional sampling, the researcher selected the fifty-four (54) students as the respondents of the study. The researcher also selected five (5) Grade 12 English Teachers, and their Communication Arts English Head Teacher in Canossa School Santa Rosa City, Laguna. There was a total of fifty-four (54) respondents. Fifteen (15) were students from Section A which is the Science, Technology, Engineering, and Mathematics (STEM) Strand. Twelve (12) students came from Section B which is still under the STEM Strand. Twelve (12) students came from Section C of another STEM Strand section, Finally, fifteen (15) students were taken from Section D which is a mixture of Humanities and Social Science (HUMSS) and Accountancy, Business, and Management (ABM) Strand, but the researcher was able to equally ask eight (8) students from ABM Strand to answer, while seven (7) came from the HUMSS Strand. The five (5) teachers are all English teachers in Grade 12 teaching Research Capstone, Qualitative Research, Quantitative Research, 21st Century Literature, and Creative Writing. The head teacher is the institutional coordinator of the Communication Arts English Department from kinder to grade 12.

\subsection{Participants of the Study}

Through the purposive random sampling, five (5) Grade 12 students together with the five (5) Grade 12 English teachers were the participants of the interview. The teachers were chosen because of the subjects they are teaching in Senior High School namely, Quantitative Research, Qualitative Research, Research Capstone, Creative Writing, and 21st Century Literature. There were five teachers and five students from Canossa School Santa Rosa City, Laguna. For the teachers, their age range is from 24, being the youngest, to 55, being the oldest. For the students, all of which are 16 years of age. Majority of the teachers and students are female. All of the teachers are Grade 12 teachers teaching different English subjects, while for the students, three of them are in STEM while the two are ABM and HUMSS students. Three of the teachers has been teaching for four to nine years while two of them had been teaching for 15 to 27 years.

\subsection{Data Gathering Procedure}

For the data gathering procedure, the researcher gave the permission and consent letters to the necessary administrators of the high school department of the chosen school for pilot testing to test the reliability of the questionnaires and tests to be given. The school has two (2) Grade 12 English teachers and one (1) subject area coordinator. The teachers were given the self-assessment for measuring their level of questioning while the assessment of the same variable for the two teachers were given to the subject-coordinator. Then, the critical thinking assessment test was given to ten (10) Grade 12 students from different strands. After the pilot testing, the results were given to the research statistician for the computation of Cronbach's Alpha Reliability Test.

After editing and revising of the instrument from the reliability test, another set of permission and consent letters were sent to the necessary administrators of the high school department of the chosen school for data gathering. After receiving approval from the principal, assistant principal, and senior high school coordinator, the researcher gave the link for the critical thinking assessment test to the fifty-four (54) Grade 12 students across different strands with the help of the class advisers. Then, a link was also given to the five (5) Grade 12 English teachers for the self-assessment of their level of questioning. Finally, another link was given to the subject area coordinator of the Communication Arts English Department for her assessment of the level of questioning of these teachers.

After the quantitative data gathering, interviews were conducted for the five Grade 12 English teachers and five Grade 12 students with the following respective interview questions. The researcher was able to use Zoom and its recording feature to save the conversation with permission from the participants. Other than this, the researcher also used Facebook Messenger when the participants were not able to use Zoom, and used another cellphone to record the conversation. Then, all of the interviews were transcribed verbatim. After which, the 
researcher made use of the NVivo 12 software, particularly the compared by number coding reference, and word cloud to determine the frequent words used during the interview. The researcher selected words that do not have any weight to the themes needed to be extracted and placed it on the stop words watch list. From there, the researcher was able to determine the common themes as superordinate and underlying subthemes or subordinate themes using the application.

\subsection{Treatment of Quantitative Data}

The following were the statistical treatments used in the study by the statistician using Statistical Package for Social Sciences (SPSS):

$>\quad$ The frequency distribution was used to determine the level of critical thinking skills among Grade 12 Senior High School Students.

$>\quad$ The simple mean and the four-point Likert Scale were used to determine the level of teachers' questioning.

$>\quad$ The independent T-test was used to determine the significant difference of the assessment between the subject teacher and head teacher or coordinator.

$>\quad$ The Pearson's R Correlation was used to determine the significant relationship of the level of teachers' questioning on students' level of critical thinking skills.

\subsection{Treatment of Qualitative Data}

After gathering all the data from the interviews conducted, the researcher transcribed the interviews with the five student and five teacher- participants. Afterwards, she extracted the similar responses of the participants and came up with subordinate themes. These themes where then clustered into superordinate themes which encapsulated the feelings, points of views, and experiences of the participants. Thereafter, observations and reflections of the researcher were derived from the themes. Supporting literature, articles, and blogs related to the same experiences in dealing with the level of critical thinking skills and teachers' questioning were also included to seal the experience.

\section{Results and Discussion}

\section{Table 1}

Level of questioning as assessed by the head teacher and themselves in terms of remembering

\begin{tabular}{lcccccc}
\hline \multicolumn{1}{c}{ Indicators in terms of Remembering } & \multicolumn{2}{c}{ Head Teacher } & \multicolumn{2}{c}{ Teachers } & \multicolumn{2}{c}{ Composite } \\
& $\mathrm{M}$ & $\mathrm{VI}$ & $\mathrm{M}$ & $\mathrm{VI}$ & $\mathrm{M}$ & $\mathrm{VI}$ \\
\hline List series of ideas about past lesson & 4.00 & $\mathrm{VH}$ & 3.00 & $\mathrm{H}$ & 3.50 & $\mathrm{VH}$ \\
Define different terms or words from previous lesson & 3.80 & $\mathrm{VH}$ & 3.20 & $\mathrm{H}$ & 3.50 & $\mathrm{VH}$ \\
Recall past ideas or lessons & 3.80 & $\mathrm{VH}$ & 3.20 & $\mathrm{H}$ & 3.50 & $\mathrm{VH}$ \\
Condense ideas from past lesson into an outline & 3.60 & $\mathrm{VH}$ & 2.20 & $\mathrm{~L}$ & 2.90 & $\mathrm{H}$ \\
Independently state ideas learned from previous lesson & 4.00 & $\mathrm{VH}$ & 3.40 & $\mathrm{VH}$ & 3.70 & $\mathrm{VH}$ \\
\hline \multicolumn{1}{c}{ GENERAL ASSESSMENT } & 3.84 & $\mathrm{VH}$ & 3.00 & $\mathrm{H}$ & 3.42 & $\mathrm{VH}$ \\
\hline
\end{tabular}

As shown in Table 1, the general composite mean on the level of questioning of Grade 12 Senior High School Teachers as assessed by the Head Teacher and themselves in terms of Remembering is 3.42 which was verbally interpreted as Very High. The indicator "Independently state ideas learned from previous lesson" had the highest computed composite mean of 3.70 and was interpreted as Very High, while the indicator "Condense ideas from past lesson into an outline" had the least computed composite mean of 2.90 which was verbally interpreted as High.

The results imply that in the levels of questioning from Bloom's Taxonomy in the Cognitive Process, the 
participating teachers evidently practiced questions that geared more on remembering. Even though the table shows that asking students to summarize what was learned into an outline was not that evident, the composite means of independently sharing what was learned from past lessons remained very evident. This mainly suggests that sharing what was learned connotes more freedom for students to express themselves rather than putting it out. But mainly, the level of remembering significantly scored very high which indicates that during classes, they were able to encourage critical thinking through this level of questioning.

From the discussion of Armstrong (2020), the level of remembering in teachers' questioning ensured that students learned specific, concise, and detailed information about the lesson. Since content knowledge is significant to the success of extracting the expected answers, questions in the remembering level are helpful for it solicits exactly these kinds of answers. Teachers ask to define, identify, recall, or recognize the lessons given from the long-term memory. In this level, teachers are encouraged to recite something that has been taught or quote information from memory based on previous lectures, readings, and the like.

\section{Table 2}

Level of questioning as assessed by the head teacher and themselves in terms of understanding

\begin{tabular}{lcccccc}
\multicolumn{1}{c}{ Indicators in Terms of Understanding } & \multicolumn{2}{c}{ Head Teacher } & \multicolumn{2}{c}{ Teachers } & \multicolumn{2}{c}{ Composite } \\
& $\mathrm{M}$ & $\mathrm{VI}$ & $\mathrm{M}$ & $\mathrm{VI}$ & $\mathrm{M}$ & $\mathrm{VI}$ \\
\hline Give another meaning to a presented idea & 3.80 & $\mathrm{VH}$ & 3.20 & $\mathrm{H}$ & 3.50 & $\mathrm{VH}$ \\
Provide an example of a concept about the lesson & 4.00 & $\mathrm{VH}$ & 3.20 & $\mathrm{H}$ & 3.60 & $\mathrm{VH}$ \\
Explain a concept or idea from the lesson & 3.80 & $\mathrm{VH}$ & 3.00 & $\mathrm{H}$ & 3.40 & $\mathrm{VH}$ \\
Abstract a theme or major point from the lesson & 3.60 & $\mathrm{VH}$ & 2.40 & $\mathrm{~L}$ & 3.00 & $\mathrm{H}$ \\
Draw a conclusion from information given & 3.60 & $\mathrm{VH}$ & 3.20 & $\mathrm{H}$ & 3.40 & $\mathrm{VH}$ \\
\hline \multicolumn{1}{c}{ GENERAL ASSESSMENT } & 3.76 & $\mathrm{VH}$ & 3.00 & $\mathrm{H}$ & 3.38 & $\mathrm{VH}$ \\
\hline
\end{tabular}

As shown in Table 2, the general composite mean on the level of questioning of Grade 12 Senior High School Teachers as assessed by the Head Teacher and themselves in terms of Understanding is 3.38 which was verbally interpreted as Very High. The indicator "Provide an example of a concept about the lesson" had the highest computed composite mean of 3.60 and was interpreted as Very High, while the indicator "Abstract a theme or major point from the lesson" had the least computed composite mean of 3.00 which was verbally interpreted as High.

The results imply that within the level of questioning in the cognitive process in terms of understanding, teachers were able to evidently facilitate questions that were under this level. Since the indicator with the lowest composite means suggests that extracting the theme or underlying idea across all subjects could not be done consistently by all participating teachers and that it only called for the need to cover every lesson. On the other hand, asking students to provide an example about the lesson implies a more common discourse between the students and teachers. Providing examples not only strengthened what the students understood, but also generated how they would be able to parallel an exact idea with their own words. This was also an opportunity for teachers to modify and provide further intervention depending on the students' answers.

Armstrong (2020) continued to discuss that questions in the understanding level expects comprehension through one or more forms of explanation from the students. Appropriate learning outcomes can ask them to abstract, discuss, or give examples connected to the lesson. Furthermore, this suggests that teachers can ask students to discuss a problem or idea in their own words in order to evaluate learning in the remembering level. This can be in a form of retelling a part of what was discussed with analogies included. This allows students to break from simply recalling by understanding what the facts mean. Questions from teachers should be able to allow the students to see and understand the main idea and interpret it in their own words.

As shown in table 3, the general composite mean on the level of questioning of Grade 12 Senior High School Teachers as assessed by the Head Teacher and themselves in terms of Applying is 3.42 which was verbally interpreted as High. The indicator "Relate acquired knowledge to real-life situations" had the highest computed composite mean of 3.70 and was interpreted as Very High, while the indicator "Apply acquired

94 Consortia Academia Publishing (A partner of Network of Professional Researchers and Educators) 
Grade 12 English teachers' questioning in developing students' critical thinking skills: A two-phase model

knowledge to familiar or unfamiliar task" and "Imagine a situation and use learned skill to solve it" both had the least computed composite mean of 3.20 which was verbally interpreted as High.

\section{Table 3}

Level of questioning as assessed by the head teacher and themselves in terms of applying

\begin{tabular}{lcccccc}
\hline \multicolumn{1}{c}{ Indicators in terms of Applying } & \multicolumn{2}{c}{ Head Teacher } & \multicolumn{2}{c}{ Teachers } & \multicolumn{2}{c}{ Composite } \\
& M & VI & M & VI & M & VI \\
\hline Solve a real-life problem through ideas learned & 3.80 & VH & 3.40 & VH & 3.60 & VH \\
Evaluate a situation and apply the best solution & 3.80 & VH & 3.00 & $\mathrm{H}$ & 3.40 & VH \\
Apply acquired knowledge to familiar or unfamiliar task & 3.60 & VH & 2.80 & $\mathrm{H}$ & 3.20 & $\mathrm{H}$ \\
Imagine a situation and use learned skill to solve it & 3.60 & $\mathrm{VH}$ & 2.80 & $\mathrm{H}$ & 3.20 & $\mathrm{H}$ \\
Relate acquired knowledge to real-life situations & 3.80 & $\mathrm{VH}$ & 3.60 & $\mathrm{VH}$ & 3.70 & $\mathrm{VH}$ \\
\hline \multicolumn{1}{c}{ GENERAL ASSESSMENT } & 3.72 & $\mathrm{VH}$ & 3.12 & $\mathrm{H}$ & 3.42 & $\mathrm{H}$ \\
\hline
\end{tabular}

The results imply that since the level of questioning in terms of applying was high, teachers' use of these questions were somehow evident in the classroom. From the table, it can be argued that there may not have been enough tasks for the students to apply what was learned or even the avenue to come up with their own compelling scenarios to apply the lesson. Consequently, being able to relate learned information to real-life situations received a very high rating with the implication that teachers might have been more religious in providing authentic and actual events that could help students analyze and apply what they knew. From this, it can be inferred that there are teachers who usually rely on lectures and do not ask questions all throughout the session. Some ask questions but it is less frequent than doing other things during class. This can be a support to the finding of the study where teachers score one point less from the highest rating in terms of asking questions in the applying level.

In support to this, the study of Alsu and Calik (2018) suggested that higher order questions are invaluable within the objectives of what this level seeks or the kind of answers this level of questioning asks. Asking students to apply what they learn requires content knowledge and basic understanding of facts and concepts which can all be gathered from questions in the lower level like remembering and understanding. Applying these concepts balances out the transition from lower level to higher level of questioning and by extension, thinking. In addition, Persaud (2019) also supported that questions in the applying level allows students to take what they learned and apply it to scenarios outside the classroom or new situations that are not given by the teachers. Other than this, students can manifest their response to these questions in other ways besides verbally or in writing, like solving problems with true-to-life application. Since it is still in the lower order level, the connection of what is learned from the lesson and in applying it is still visible.

\section{Table 4}

Level of questioning as assessed by the head teacher and themselves in terms of analyzing

\begin{tabular}{lcccccc}
\hline \multicolumn{1}{c}{ Indicators in Terms of Analyzing } & \multicolumn{2}{c}{ Head Teacher } & \multicolumn{2}{c}{ Teachers } & \multicolumn{2}{c}{ Composite } \\
& M & VI & M & VI & M & VI \\
\hline $\begin{array}{l}\text { Break ideas into parts and relate it to the overall structure or } \\
\text { purpose }\end{array}$ & 3.60 & $\mathrm{VH}$ & 3.00 & $\mathrm{H}$ & 3.30 & $\mathrm{VH}$ \\
& & & & & & \\
Distinguish relevant from irrelevant parts of a given information & 3.80 & $\mathrm{VH}$ & 2.60 & $\mathrm{H}$ & 3.20 & $\mathrm{H}$ \\
$\begin{array}{l}\text { Determine biases, values, or intent from presented materials } \\
\text { Determine how one idea is part of the whole concept of the lesson }\end{array}$ & 3.80 & $\mathrm{VH}$ & 2.60 & $\mathrm{H}$ & 3.20 & $\mathrm{H}$ \\
Find evidences to support the general concept of the lesson & 3.80 & $\mathrm{VH}$ & 3.20 & $\mathrm{H}$ & 3.40 & $\mathrm{VH}$ \\
\hline \multicolumn{1}{l}{ GENERAL ASSESSMENT } & 3.72 & $\mathrm{VH}$ & 2.88 & $\mathrm{H}$ & 3.30 & $\mathrm{VH}$ \\
\hline
\end{tabular}

As shown in Table 4, the general composite mean on the level of questioning of Grade 12 Senior High School Teachers as assessed by the Head Teacher and themselves in terms of Analyzing was 3.30 which was verbally interpreted as Very High. The indicator "determine how one idea is part of the whole concept of the lesson" and "Find evidences to support the general concept of the lesson" both had the highest computed composite mean of 3.40 and was interpreted as Very High while the indicator "Distinguish relevant from irrelevant parts of a given information" and "Determine biases, values, or intent from presented materials" both 
Gacutan, S. A. B., \& Recillo, M. L. B.

had the least computed composite mean of 3.20 which was verbally interpreted as High.

This implies that the level of questioning of teachers in analyzing was very evident in support to the two indicators which scored very high among the five. Also, teachers were successful in making the students find the connection among the ideas that were introduced to the lesson and find how each was a supporting detail or evidence to the general thought. In contrast, this also suggests that despite the linkages among these ideas, it was not as evident to teachers asking students to filter these details as to which was irrelevant and which was biased.

The study of Davoudi and Sadeghi (2015) also supported the claim that since teachers are not familiar with the in-depth capacity of asking in the analyzing level and in extension to the higher levels of questioning, students cannot be aided in removing uncertainties and biases, and also fully analyzing the entire idea. It breaks the relationship between questioning and deeper thought processes of students. In addition, Kelly (2020) discussed that in the analyzing stages, teachers ask questions so that students can find patterns in what they learn. They move beyond simply remembering, understanding, and applying. It activates a more active role in their own learning. The finding also shows that teachers are able to aid students through questioning in the breaking down of materials given into constituent parts and determine how they are related to one another or to an overall structure or purpose.

\section{Table 5}

Level of questioning as assessed by the head teacher and themselves in terms of evaluating

\begin{tabular}{|c|c|c|c|c|c|c|}
\hline \multirow{2}{*}{ Indicators in Terms of Evaluating } & \multicolumn{2}{|c|}{ Head Teacher } & \multicolumn{2}{|c|}{ Teachers } & \multicolumn{2}{|c|}{ Composite } \\
\hline & $\mathrm{M}$ & VI & M & VI & M & VI \\
\hline $\begin{array}{l}\text { Detect inconsistencies and/or fallacies from a given process or } \\
\text { product }\end{array}$ & 3.80 & $\mathrm{VH}$ & 2.80 & $\mathrm{H}$ & 3.30 & VH \\
\hline Present an opinion by making judgement about the information & 3.80 & $\mathrm{VH}$ & 3.20 & $\mathrm{H}$ & 3.50 & VH \\
\hline Identify the importance of given ideas from the lesson & 3.80 & $\mathrm{VH}$ & 3.00 & $\mathrm{H}$ & 3.40 & $\mathrm{VH}$ \\
\hline Assess the validity of ideas given based on a criteria presented & 3.80 & $\mathrm{VH}$ & 3.20 & $\mathrm{H}$ & 3.50 & $\mathrm{VH}$ \\
\hline Evaluate ideas given from the lesson for improvement & 3.80 & $\mathrm{VH}$ & 3.00 & $\mathrm{H}$ & 3.40 & $\mathrm{VH}$ \\
\hline GENERAL ASSESSMENT & 3.80 & $\mathrm{VH}$ & 3.04 & $\mathrm{H}$ & 3.42 & VH \\
\hline
\end{tabular}

As shown in Table 5, the general composite mean on the level of questioning of Grade 12 Senior High School Teachers as assessed by the Head Teacher and themselves in terms of evaluating is 3.42 which was verbally interpreted as Very High. The indicator "Present an opinion by making judgement about the information" and "Assess the validity of ideas given based on a criteria presented" both had the highest computed composite mean of 3.50 and were interpreted as Very High, while the indicator "Detect inconsistencies and/or fallacies from a given process or product" had the least computed composite mean of 3.30 which was verbally interpreted as Very High. This implies that the teachers' level of questioning in the evaluating level was very evident and that the teachers were able to provide an avenue for students to share their opinion about the lesson and provide necessary criteria to different outputs while including them in the evaluating process. Teachers were also successful in allowing students to detect inconsistencies within their works or other examples provided. This suggests an intrinsic way of thinking not just for what the idea looked like at a glance but also its coherence.

In addition to this, Persaud (2018) supported this outcome as she related that questions asked within this level allows students to make educated judgments about the value of the materials they learned, apply and analyze like what was stated in the latter levels, and be able to tell the difference between fact, opinion, and even inferences. This includes justifying a specific decision and being able to back up that justification with content knowledge and sound reasoning. This includes appraising, critiquing, and even supporting ideas given. Furthermore, students were able to make them because of the criteria and standards given. Furthermore, Yang (2017) supported this as he stated that through questioning, it starts the dialogue with the students and initially allows them to be more active with the discussion. In addition, because of prompting motivation and interest from the students, there is feedback to and from the students as they continue to give or receive evaluations. This in turn, is an actual response to what both lack. In this sense, this study asserts without a platform for students to 
Grade 12 English teachers' questioning in developing students' critical thinking skills: A two-phase model

do evaluation and for teachers to ask such level of question, low level of questioning will remain.

\section{Table 6}

Level of questioning as assessed by the head teacher and themselves in terms of creating

\begin{tabular}{lcccccc}
\multicolumn{1}{c}{ Indicators in Terms of Creating } & \multicolumn{2}{c}{ Head Teacher } & \multicolumn{2}{c}{ Teachers } & \multicolumn{2}{c}{ Composite } \\
& $\mathrm{M}$ & $\mathrm{VI}$ & $\mathrm{M}$ & $\mathrm{VI}$ & $\mathrm{M}$ & $\mathrm{VI}$ \\
\hline Provide an assumption from the idea about the lesson & 3.80 & $\mathrm{VH}$ & 2.60 & $\mathrm{H}$ & 3.20 & $\mathrm{H}$ \\
Give the procedure in accomplishing tasks & 4.00 & $\mathrm{VH}$ & 3.40 & $\mathrm{VH}$ & 3.70 & $\mathrm{VH}$ \\
Propose an alternate solution to an idea & 3.60 & $\mathrm{VH}$ & 3.20 & $\mathrm{H}$ & 3.40 & $\mathrm{VH}$ \\
Express or write their answer about the lesson & 3.80 & $\mathrm{VH}$ & 3.20 & $\mathrm{H}$ & 3.50 & $\mathrm{VH}$ \\
Combine concepts together to create a meaningful output & 3.80 & $\mathrm{VH}$ & 3.80 & $\mathrm{VH}$ & 3.30 & $\mathrm{VH}$ \\
\hline \multicolumn{1}{c}{ GENERAL ASSESSMENT } & 3.80 & $\mathrm{VH}$ & 3.04 & $\mathrm{H}$ & 3.42 & $\mathrm{VH}$ \\
\hline
\end{tabular}

As shown in Table 6, the general composite mean on the level of questioning of Grade 12 Senior High School Teachers as assessed by the Head Teacher and themselves in terms of creating is 3.42 which was verbally interpreted as Very High. The indicator "Give the procedure in accomplishing tasks" had the highest computed composite mean of 3.50 and were interpreted as Very High, while the indicator "Provide an assumption from the idea about the lesson" had the least computed composite mean of 3.20 which was verbally interpreted as High. This implies that the level of questioning in terms of creating was very evident and that the teachers were able to ask students to construct the necessary steps in accomplishing tasks that were given to them in their respective English subjects. Furthermore, they were able to share their understanding of the lessons into meaningful outputs. Though the indicator of being able to ask for assumptions about the lesson, this talks about the necessary assumptions needed to be made based on the different evidence and information given and not just some baseless claim.

The discussion of Kelly (2020) supported this by stating that in this level, students move beyond relying on previously learned information and analyzing items that the teachers gave them. Instead, they created new products, ideas, and theories. They put elements together to form a new coherent or functional whole and had also reorganized elements into a new pattern or structure. Based on the final level of Bloom's taxonomy, the students demonstrated full knowledge by applying what they learned, analyzed, evaluated, and built something, either tangible or conceptual. To add, from the study of Aslansoy et al. (2016), their study suggested a planned preparation and exposure to the use of high level questioning such as evaluating and creating despite their study finding teachers using them because their study identified the purpose of why they used higher order questions and that was to manage and discipline the students which clearly should not be the purpose of questions. In the succeeding discussions of the qualitative part of this research, it can be implied that training in the construction and use of higher-level questions is vital, especially in the promotion of deeper thought process among students.

Table 7

Level of critical thinking skills in terms of evaluating assumptions

\begin{tabular}{|c|c|c|}
\hline Indicators & $\mathrm{f}$ & $\%$ \\
\hline Outstanding & 5 & 9.26 \\
\hline Very Satisfactory & 0 & 0.00 \\
\hline Satisfactory & 18 & 33.33 \\
\hline Fairly Satisfactory & 0 & 0.00 \\
\hline Did not Meet Expectations & 31 & 57.41 \\
\hline & 54 & 100.00 \\
\hline
\end{tabular}

Table 7 shows the level of critical thinking skills among Grade 12 Senior High School Students in terms of Evaluating Assumptions. Thirty-one (31) out of fifty-four (54) students or 57.41\% Did Not Meet Expectations, while five students or $9.26 \%$ had a rating of Outstanding. Finally, eighteen (18) or $33.33 \%$ of the students got a rating of Satisfactory. The results imply that the given number of students whose scores did not meet the expectations failed to comprehend ideas given by their subject teachers or actually understood the ideas given and considered whether it was true or not. It also implies that further interventions should have been designed around this skill in English so as to meet the supposed level. 
In support of these idea, Saez (2017) implied in his study that there are some individuals who are more adept when it comes to being skeptical and analytical in evaluating assumptions. Those who lack these basic skills in critical thinking have the tendency to be more easily accepting of ideas because of their face value even without further evaluation. He focuses more on what to think and not much so on how to think; hence, the process of comprehending ideas given proves to be problematic. In addition, Barshay (2019) pointed out that the goal of developing students' skill of evaluating, analyzing, and synthesizing these kinds of assumptions is paramount but he highlighted the role of content knowledge as one solution to make these skills effective. He suggested that the best approach is to explicitly teach specific small skills of analysis for each subject, in this case English subjects in the Grade 12 level, and not treat them as one united body knowledge for it will draw the students back to chunking information, defeating the purpose of developing an effective skill of evaluating assumptions.

\section{Table 8}

Level of critical thinking skills in terms of recognizing assumptions

\begin{tabular}{|c|c|c|}
\hline Indicators & $\mathrm{f}$ & $\%$ \\
\hline Outstanding & 2 & 3.70 \\
\hline Very Satisfactory & 0 & 0.00 \\
\hline Satisfactory & 6 & 11.11 \\
\hline Fairly Satisfactory & 0 & 0.00 \\
\hline Did not Meet Expectation & 46 & 85.18 \\
\hline & 54 & 100.00 \\
\hline
\end{tabular}

Table 8 shows the level of critical thinking skills among Grade 12 Senior High School Students in terms of Recognizing Assumptions. Forty-six (46) out of fifty-four (54) students or 85.18\% Did Not Meet Expectations. On the other hand, two (2) or $3.70 \%$ got an Outstanding rating. Finally, six (6) or $11.11 \%$ got a rating of Satisfactory. The results show that the majority of the respondents' skill in recognizing assumptions was significantly low. It also implies that their ability to identify ideas or evidence to support the assumption or even collecting key ideas about the information given was lacking. This also suggests that their ability to respond and questions assumptions given was problematic and that they were not able to manifest further ideas that could be explored since preliminary ideas given were assumptions.

Similarly, Rusbult (2018) discussed that the skills of critical thinking demands to be developed all from the evaluating assumptions until drawing inferences since skipping one skill removes students' opportunity for deeper thinking. Thus, this intensifies the need for intervention to improve this skill to continue the prerequisite streak of critical thinking. With this, the study of Chikiwa and Schafer (2018) asserted that in order for students to be given opportunity for such intervention, thinking takes effect largely because of questions and prompts given by teachers. This may lead them to more than just recognize assumptions and actually make claims that are empirical.

\section{Table 9}

Level of critical thinking skills in terms of analyzing arguments

\begin{tabular}{|c|c|c|}
\hline Indicators & $\mathrm{f}$ & $\%$ \\
\hline Outstanding & 26 & 48.15 \\
\hline Very Satisfactory & 0 & 0.00 \\
\hline Satisfactory & 11 & 20.37 \\
\hline Fairly Satisfactory & 0 & 0.00 \\
\hline Did not Meet Expectation & 17 & 31.48 \\
\hline & 54 & 100.00 \\
\hline
\end{tabular}

Table 9 shows the level of critical thinking skills among Grade 12 Senior High School Students in terms of Analyzing Arguments. Twenty-six (26) out of fifty-four (54) students or $48.15 \%$ scored a rate of Outstanding. On the other hand, seventeen (17) or 31.48\% Did Not Meet Expectations. Finally, eleven (11) or 20.37\% got a rating of Satisfactory. This implies that the given number of students were able to successfully analyze the 
information objectively and accurately. They were also able to assess the quality of the supporting details given in the questions and were objective in sorting through the validity in drawing more accurate conclusions or answers. They were also able to identify the relevance of each option together with those which were irrelevant. Finally, they were also able to see the similarities and difference among options and to identify the best and most accurate argument.

To add, Su et al. (2016) supported that this is an indication that students can think disparagingly and evaluate the advantages and disadvantages across different arguments, and self-direct themselves to point out the strongest argument. They also emphasized the teachers' role in zeroing in on the characteristics of strategies that further promote critical thinking to avoid relapse despite seeing promising results in the students' performance. It is the kind of complacency that inhibits students to link the critical thinking skills together and direct them to deeper thinking. Even the study of Cazares (2016) mentioned the continuous effort to develop the skill of questioning the quality of evidences because of how abundant the arguments and ideas presented to students are and since it looks logical at first glance, students tend to abandon the need for further investigation and thought process because of its face value. Cazares continued to assert that gathering empirical evidence, comprehend and use language with accuracy, and recognize existence and absence of logical relationship between ideas and the like will render accurate judgement about specific things and the quality of life.

\section{Table 10}

Level of critical thinking skills in terms of deduction

\begin{tabular}{|c|c|c|}
\hline Indicators & $\mathrm{f}$ & $\%$ \\
\hline Outstanding & 13 & 24.07 \\
\hline Very Satisfactory & 0 & 0.00 \\
\hline Satisfactory & 14 & 25.93 \\
\hline Fairly Satisfactory & 0 & 0.00 \\
\hline Did not Meet Expectation & 27 & 50.00 \\
\hline & 54 & 100.00 \\
\hline
\end{tabular}

Table 10 shows the level of critical thinking skills among Grade 12 Senior High School Students in terms of Deduction. Twenty-seven (27) out of fifty-four (54) students or 50\% Did Not Meet Expectations. On the other hand, thirteen (13) or $24.07 \%$ had a rating of Outstanding. Finally, fourteen (14) or $25.93 \%$ got a rating of Satisfactory. This implies that the given number of students were not able to identify strong premises that could arrive at the different general ideas mentioned. They lacked the skill to review and monitor the possible connection between the array of options given and the statements beforehand. With this, having a firm grasp of either the problem or the situation was not evident, which was a necessary step in order to find the premise that could lead to the main idea. This also implies that they were not successful in providing their own understanding of the idea mentioned and match it up to the possible answers given to them.

In relation to this, to Hitchcock (2018), the skill of deduction requires systematic monitoring of thought and analyzing data to be used in reasoning which much lead to implications and strong premises that would lead to basic inferences. That is why educational interventions must be created to improve this skill particularly, dialogue, anchored instruction, and mentoring. Since deductive thinking is a necessary skill across other subjects besides English, it also emphasizes that it is again a prerequisite to the other skills of critical thinking.

That is why according to Stockdale and Williams (2015), students' work habits and instructor assistance could make a substantial difference in performance. Their research suggested that these students would have work-habit deficiencies related to both the amount and type of effort they put into it. Because of this, teachers should be able to direct the efforts students put into thinking and learning into a systematic process which critical thinking promotes. Deduction is a skill which looks into the general idea and lets thinkers add pieces of information related to it so that they can arrive at a good conclusion or answer. 
Gacutan, S. A. B., \& Recillo, M. L. B.

\section{Table 11}

Level of critical thinking skills in terms of drawing information

\begin{tabular}{|c|c|c|}
\hline Indicators & $\mathrm{f}$ & $\%$ \\
\hline Outstanding & 25 & 46.29 \\
\hline Very Satisfactory & 0 & 0.00 \\
\hline Satisfactory & 10 & 18.52 \\
\hline Fairly Satisfactory & 0 & 0.00 \\
\hline Did not Meet Expectation & 19 & 35.19 \\
\hline Total & 54 & 100.00 \\
\hline
\end{tabular}

Table 11 shows the level of critical thinking skills among Grade 12 Senior High School Students in terms of Drawing Information. Twenty-five (25) out of fifty-four (54) students or 46.29\% had a rating of Outstanding. On the other hand, ten (10) or $18.52 \%$ got a Satisfactory rating. Finally, nineteen (19) or $25.93 \%$ Did Not Meet Expectations. This implies that a significant number of students were able to identify the information that was still needed from the given idea and the connected ideas as evidence. They were also able to interpret the information to draw out a conclusion by analyzing how it should have been done and also paid attention on how to interpret the idea. It also implies that they were able to find different reasons why they chose their answers as the most accurate ones and why the others were not.

The researcher sees the significance of the discussion of Cottrell (2017) because it stated that the advances made in knowledge and the evidence that standards are met are groundworks for the continuous pursuit of improvement to what has gone before. Since it is easier for students to repeat what they just acquired through their senses without giving it much thought, there is still room for enhancement. Even though the majority of the respondents were able to score an above satisfactory rate, close to half of their sample population did not meet the necessary expectations within the level of critical thinking in terms of drawing information.

Table 12

Level of critical thinking skills in terms of drawing inferences

\begin{tabular}{lccc}
\hline & Indicators & $\mathrm{f}$ & $\%$ \\
\hline Outstanding & & 23 & 42.59 \\
Very Satisfactory & & 0 & 0.00 \\
Satisfactory & & 11 & 20.37 \\
Fairly Satisfactory & & 0 & 0.00 \\
Did not Meet Expectation & & 20 & 37.04 \\
\hline & Total & 54 & 100.00 \\
\hline
\end{tabular}

Table 12 shows the level of critical thinking skills among Grade 12 Senior High School Students in terms of Drawing Inferences. Twenty-three (23) out of fifty-four (54) students or $42.59 \%$ had a rating of Outstanding. On the other hand, eleven (11) or $20.37 \%$ had a Satisfactory rating. Finally, twenty (20) or 37.04\% Did Not Meet Expectations. This implies that the number of students were able to select the best possible solution to the given idea by evaluating all facts and coming up with the best judgement as to why they chose their answers. Furthermore, they were able to see the connected idea which was the best conclusion that could be made. Generalizations were also made by interpreting the statements given that could also be used in makeing hypotheses. Finally, this implies that they were able to solicit new evidences that could impact their decision of choosing the best answer.

In addition, in the study of Kendeou (2015), despite the conflicting ideas of critical thinking, drawing inferences was said to be one of the cornerstones of this kind of thinking and comprehension. Inference ability has emerged as one of the unique and significant predictors of reading comprehension as well in the expansive studies for students across levels. It not only ties deeper thinking all together but also finishes the systematic process of critical thinking. It is a fundamental step in helping students direct their course of thinking into specific goals or set solutions to problems given by expansively analyzing all possible evidences given. 
Grade 12 English teachers' questioning in developing students' critical thinking skills: A two-phase model

The study of Tachi (2015) also emphasized that even though drawing inferences is the most important predictor of higher order skills and comprehension, there are only few effective strategies that could help improve and develop this. That is why it cannot be overstated that this goal is important especially in building evidence-based classroom practices to address the multidimensionality of inference making.

Table 13

ANOVA in terms of remembering, understanding, applying, analyzing, evaluating, and creating

\begin{tabular}{|c|c|c|c|c|c|c|c|}
\hline & $\begin{array}{c}\text { Sum of } \\
\text { squares }\end{array}$ & Df & $\begin{array}{c}\text { Mean } \\
\text { square }\end{array}$ & F Ratio & Sig. & Remarks & Decision \\
\hline Remembering Between Group & 1.764 & 1 & 1.764 & 32.667 & .000 & Significant & Reject \\
\hline Within Groups & .432 & 8 & .054 & & & & $\mathrm{H}_{\mathrm{o}}$ \\
\hline Total & 2.196 & 9 & & & & & \\
\hline Understanding Between Groups & 1.444 & 1 & 1.444 & 8.299 & .020 & Significant & Reject \\
\hline Within Groups & 1.392 & 8 & .174 & & & & $\mathrm{H}_{\mathrm{o}}$ \\
\hline Total & 2.836 & 9 & & & & & \\
\hline Applying Between Groups & .900 & 1 & .900 & 4.455 & .068 & Not & Accept \\
\hline Within Groups & 1.616 & 8 & .202 & & & Significant & $\mathrm{Ho}_{\mathrm{o}}$ \\
\hline Total & 2.516 & 9 & & & & & \\
\hline Analyzing Between Groups & 1.764 & 1 & 1.764 & 8.733 & .018 & Significant & Reject \\
\hline Within Groups & 1.616 & 8 & .202 & & & & $\mathrm{H}_{\mathrm{o}}$ \\
\hline Total & 3.380 & 9 & & & & & \\
\hline Evaluating Between Groups & 1.444 & 1 & 1.444 & 8.805 & .018 & Significant & Reject \\
\hline Within Groups & 1.312 & 8 & .164 & & & & $\mathrm{H}_{\mathrm{o}}$ \\
\hline Total & 2.756 & 9 & & & & & \\
\hline Between Groups & 1.444 & 1 & 1.444 & 7.848 & .023 & Significant & Reject \\
\hline Within Groups & 1.472 & 8 & .184 & & & & $\mathrm{H}_{\mathrm{o}}$ \\
\hline Total & 2.916 & 9 & & & & & \\
\hline
\end{tabular}

Table 13 shows the test for significant difference in the assessment of the head teacher and teachers based on the levels of teachers' questioning in terms of remembering, understanding, applying, analyzing, evaluating, and creating. The generated computed probability values of Remembering, Understanding, Analyzing, Evaluating and Creating were $.000, .020, .018, .018$, and .023 , respectively, which were less than the level of significance of 0.05 ; thus, the null hypothesis is rejected. Therefore, there a is significant difference between the responses of the two groups of respondents on the teachers' level of questioning in the cognitive process.

On the other hand, the generated computed probability value of Applying was .068 which was greater than the level of significance of 0.05 ; thus, the null hypothesis is accepted. Therefore, there is no significant difference between the responses of the two groups of respondents on the level of teachers' questioning in the cognitive process on applying. This simply means that the responses of the head teacher and teachers themselves were different in terms of Remembering, Understanding, Analyzing, Evaluating and Creating; and that the level of questioning from the stated cognitive processes had something to do with the classification of the groups of respondents. The respondents observed different phenomena as to the level of questioning of the Grade 12 Senior High School English Teachers in Canossa School, Santa Rosa City.

Hall (2016) supported the idea that subject teachers are the primary element in using questions to aid students in the entire process of learning. They are in the forefront of identifying knowledge gaps and are the main providers for interaction. It highlights the role of the subject teachers themselves in constructing questions to develop deeper way of thinking. Even in the study of Sano (2018), teachers were the main respondents of his study which supported his findings about the vitality of planning specific questions beforehand to minimize teachers making assumptions about the students' understanding of concepts taught in the classroom. In addition, the study of Podgornik and Vogrinc (2017) supported the findings of the research wherein it stated that head teachers were convinced on the importance of the difference evaluations among groups including subject teachers because of its empirical interpretation of results, report writing, and setting of evaluation goals. The head teachers perceived the performance of evaluations as a permanent and important professional task that was prerequisite to successful quality assessment and assurance but was structured for different groups that it catered. 
Gacutan, S. A. B., \& Recillo, M. L. B.

This, in turn, was a key factor in the mutual trust, cooperation between workers, and personal assistance given to one another.

\section{Table 14}

Correlations between the teachers' level of questioning and students' level of critical thinking skills

\begin{tabular}{|c|c|c|c|c|c|}
\hline $\begin{array}{l}\text { Teachers' Questioning in } \\
\text { the Cognitive Process }\end{array}$ & $\begin{array}{c}\text { Students' Level of Critical Thinking } \\
\text { Skill }\end{array}$ & r value & $P$ value & Remarks & Decision \\
\hline \multirow{6}{*}{ Remembering } & Evaluating assumptions & .606 & .279 & Not Significant & Accept $\mathrm{H}_{0}$ \\
\hline & Recognizing assumptions & .641 & .244 & Not Significant & Accept $\mathrm{H}_{0}$ \\
\hline & Analyzing arguments & -.045 & .942 & Not Significant & Accept $\mathrm{H}_{0}$ \\
\hline & Deduction & .162 & .795 & Not Significant & Accept $\mathrm{H}_{0}$ \\
\hline & Drawing information & -.433 & .466 & Not Significant & Accept $\mathrm{H}_{0}$ \\
\hline & Drawing inferences & -.803 & .101 & Not Significant & Accept $\mathrm{H}_{\mathrm{o}}$ \\
\hline \multirow{6}{*}{ Understanding } & Evaluating assumptions & 659 & .227 & Not Significant & Accept $\mathrm{H}_{\mathrm{o}}$ \\
\hline & Recognizing assumptions & .470 & .425 & Not Significant & Accept $\mathrm{H}_{0}$ \\
\hline & Analyzing arguments & .092 & .884 & Not Significant & Accept $\mathrm{H}_{0}$ \\
\hline & Deduction & .261 & 671 & Not Significant & Accept $\mathrm{H}_{0}$ \\
\hline & Drawing information & -.130 & .835 & Not Significant & Accept $\mathrm{H}_{0}$ \\
\hline & Drawing inferences & -.777 & .122 & Not Significant & Accept $\mathrm{H}_{0}$ \\
\hline \multirow{6}{*}{ Applying } & Evaluating assumptions & .623 & .261 & Not Significant & Accept $\mathrm{H}_{0}$ \\
\hline & Recognizing assumptions & .631 & .254 & Not Significant & Accept $\mathrm{H}_{\mathrm{o}}$ \\
\hline & Analyzing arguments & -.029 & .963 & Not Significant & Accept $\mathrm{H}_{0}$ \\
\hline & Deduction & .177 & .776 & Not Significant & Accept $\mathrm{H}_{0}$ \\
\hline & Drawing information & -.403 & .501 & Not Significant & Accept $\mathrm{H}_{\mathrm{o}}$ \\
\hline & Drawing inferences & -.814 & .094 & Not Significant & Accept $\mathrm{H}_{0}$ \\
\hline \multirow{6}{*}{ Analyzing } & Evaluating assumptions & .623 & .261 & Not Significant & Accept $\mathrm{H}_{0}$ \\
\hline & Recognizing assumptions & .631 & .254 & Not Significant & Accept $\mathrm{H}_{\mathrm{o}}$ \\
\hline & Analyzing arguments & -.029 & .963 & Not Significant & Accept $\mathrm{H}_{0}$ \\
\hline & Deduction & .177 & .776 & Not Significant & Accept $\mathrm{H}_{\mathrm{o}}$ \\
\hline & Drawing information & -.403 & .501 & Not Significant & Accept $\mathrm{H}_{0}$ \\
\hline & Drawing inferences & -.815 & .093 & Not Significant & Accept $\mathrm{H}_{\mathrm{o}}$ \\
\hline \multirow{6}{*}{ Evaluating } & Evaluating assumptions & .480 & .413 & Not Significant & Accept $\mathrm{H}_{\mathrm{o}}$ \\
\hline & Recognizing assumptions & .647 & .238 & Not Significant & Accept $\mathrm{H}_{0}$ \\
\hline & Analyzing arguments & -.122 & .845 & Not Significant & Accept $\mathrm{H}_{0}$ \\
\hline & Deduction & .076 & .904 & Not Significant & Accept $\mathrm{H}_{0}$ \\
\hline & Drawing information & -.552 & .334 & Not Significant & Accept $\mathrm{H}_{0}$ \\
\hline & Drawing inferences & -.696 & .192 & Not Significant & Accept $\mathrm{H}_{0}$ \\
\hline \multirow{6}{*}{ Creating } & Evaluating assumptions & .662 & .224 & Not Significant & Accept $\mathrm{H}_{0}$ \\
\hline & Recognizing assumptions & .568 & .317 & Not Significant & Accept $\mathrm{H}_{0}$ \\
\hline & Analyzing arguments & .032 & .959 & Not Significant & Accept $\mathrm{H}_{0}$ \\
\hline & Deduction & .226 & .714 & Not Significant & Accept $\mathrm{H}_{0}$ \\
\hline & Drawing information & -.275 & .654 & Not Significant & Accept $\mathrm{H}_{0}$ \\
\hline & Drawing inferences & -.821 & .088 & Not Significant & Accept $\mathrm{H}_{0}$ \\
\hline
\end{tabular}

Notes. ${ }^{* *}$ Correlational at the level $0.01,{ }^{*}$ Correlational at the level 0.05(Two-tailed).

As shown in Table 14, the computed probability values were greater than the level of significant $(\mathrm{P}>0.05)$; thus, the null hypothesis is accepted. The results show that there is no significant relationship between the level of teachers' questioning and the students' critical thinking skills. This implies that the Grade 12 English teachers' level of questioning did not affect the development of critical thinking skills among the Grade 12 Senior High School Students. This also connotes that even though the level of questioning across the cognitive process resulted in some as "High" or "Very High" after the head teacher and self-assessments, it did not primarily have any relationship with the development of the students' critical thinking ability. Despite the findings of the study, the researcher will continue to provide the enhancement programs that may be proposed to improve the two variables separately and independently. To add, the non-evidence of relationship between the level of questioning of the teachers and the level of the students critical thinking skills is supported by the study done by Barshay (2019) where he emphasized that even through an array of attempts posted by the educational sector with different interventions, the critical thinking of students has been inconsistent throughout the years and does not provide long lasting improvements for students. Instead, he cited Willingham (2019) and his study which focused on content knowledge of the subject matter.

In addition, the study of Denton (as cited by Holster, 2017), stated that it is more crucial to consider questions which elicit higher-order thinking as opposed to identifying higher-order questions because asking higher order questions does not simply improve student learning. Coding of question types needs to consider the 
pedagogy behind the question in relation to the task rather than just the question itself. So, a question cannot be viewed in isolation from whether it can be considered higher-order. It must be viewed in the context in which it was posed. Furthermore, it is possible that teachers ask higher order questions, but the subsequent questions do not thus likely to inhibit higher order of thinking. Moreover, this result mirrors the study of Anderson (2015) where it indicated that students more likely to develop their critical thinking and pose higher order questions themselves if they are exposed to it more. It said that if students are continually reminded to do so, at least at the beginning of the lesson, then they will be more likely to immerse in deeper thinking. His study shows that there is a significant difference in the number of indicators for critical thinking between students who are asked more reflective questions. This highlights the importance of practicing the strategies until students have mastered it.

The result also relates to the study of Alshenqueeti (2015) where she asserted that it may well not be sufficient to look at the structure or type of questions merely by seeking to capture closely the functions of, and modifications to, teachers' questions as much as the data permitted. It can be more helpful if a research study inquires how the question, as it is or modified, function within the stream of classroom discourse. Finally, the discussion of Gignac and Zajenkowski (2020) focused on the Dunning-Krueger effect on people's estimation of their ability to which it depends upon possessing the ability in question. It is said that people with lower levels of specific abilities tend to self-assess their ability less than people who have relatively higher levels of ability. It was supported also from their 2019 study of the Dunning-Krueger effect where only 5\% of their respondents saw themselves as below average in intelligence and the rest self-reported themselves to have higher intelligence. This encompasses the "better-than-average effect" which encompasses also the makings of the apparent evidence for the Dunning-Krueger effect. With this study at hand, the researcher believes that upon the self-evaluation of the teachers of their level of questioning during their classes, this phenomenon took effect, thus viewing their ability high or very high as opposed to the findings of their students' critical thinking skills.

\section{Conclusion}

On the Level of Critical Thinking Skills of Students - Based on the aforementioned findings of the study, the following conclusions have been derived: hat the given number of students whose scores did not meet the expectations failed to comprehend ideas given by their subject teachers or actually understand the ideas given and consider whether it is true or not, that students' ability to respond and questions assumptions given is problematic and that they may not be able to manifest further ideas that can be explored since preliminary ideas given are assumptions, that students were able to assess the quality of the supporting details given in the questions and were objective in sorting through the validity in drawing more accurate conclusions or answers, that students were not able to identify strong premises that can arrive to the different general ideas mentioned, that the students given where able to identify what are the information still needed from the given idea and identify connected ideas as evidence, that students given were able to select the best possible solution to the given idea by evaluating all facts and coming up with the best judgement as to why they chose their answers.

Level of Questioning of Teachers - Other than this, that in the Levels of questioning from Bloom's Taxonomy in the Cognitive Process, the participating teachers evidently practice questions that gears more on remembering, that within the level of questioning in the cognitive process in terms of understanding, teachers were able to evidently facilitate questions that fall under this level, that since the level of questioning in terms of applying is high, teachers' use of these questions are somehow evident in the classroom, that teachers were successful in making the students find the connection among the ideas that were introduced to the lesson and find how each is a supporting detail or evidence to the general thought, hat the teachers' level of questioning in the evaluating level is very evident and that the teachers were able to provide and avenue for students to share their opinion about the lesson and provide necessary criteria to different outputs while including them in the evaluating process, that the level of questioning in terms of creating is very evident and that the teachers were able to ask students to construct the necessary steps in accomplishing tasks that where given to them in their respective English subjects, that the responses of the head teacher and teachers themselves are the different in terms of Remembering, Understanding, Analyzing, Evaluating and Creating and that the level of questioning 
from the stated cognitive processes has something to do with the classification of the group of participants, but the responses of head teacher and teachers are the same in terms of applying, and that questions under the applying level has nothing to do with the classifications of the group of participants, that the Grade 12 English teachers' level of questioning does not affect the development of critical thinking skills among the Grade 12 Senior High School Students and that even though the level of questioning across the cognitive process resulted to some as "High" or "Very High" after the head teacher and self-assessments, it does not primarily have any relationship with the development of the students' critical thinking ability, and that the developed work plan entitled, Classroom Q and A: Levelling Up of Students' Critical Thinking and Teachers' Questioning is absolutely necessary as a tool to help schools that also aims to address through interventions the level of their teachers' questioning and students' critical thinking skills.

From the phenomenological inquiries on the testimonies of teachers and their level of questioning and the students' level of critical thinking skills, five (5) superordinate themes emerged. They are as follows: Varied Levels of Questions, Varied Students Responses, Changes in Students' Answers, and Strategies in Improving and Developing Critical Thinking Skills.

On the Emerging Themes from Testimonies of Participants - Under the first theme, it was explored that the different types of questions teachers ask during class was determined through the choices of the teacher of what level of question is the most appropriate in that moment in their lesson. It was seen that teachers asked students to first define or give meaning to certain terms related to their subject before starting the discussion of the lesson itself. It is also seen from their accounts that they transition from a remembering level of questioning to the applying level where they ask the students for their personal point-of-view after much discussion has been made. Furthermore, it is evident that only a few teachers were able to reach the creating level of questioning wherein some teachers instruct students for a research paper or essay as an output. Nevertheless, students receive the avenue for deeper thinking because of the different kinds of questions teachers ask them. Follow-up questions are also widely used by the teachers because of the authentic experience of some students needing it when they are asked. With this, this just proves that Grade 12 English Teachers are dynamic and well-versed with wielding the power of questioning and its influence in the critical thinking of their students, but the consistency and mastery of all teachers in the area needs improvement.

Following this premise is the second theme that emerged from the students when they were asked what are the kinds of questions that their teachers ask them, balancing out the perspective of the same question from the first theme but from the students themselves. It was noted that students saw the variety of questions that their teachers used like asking to define certain terminologies and asking for their opinion on different issues. Moreover, managerial or routine questions were also stated wherein they ask mainly to ask if there are interruptions during class, is the teacher being understood, and the like. But it was also accounted that there are some teachers who do not ask questions within the duration of their class, mainly discussing on and on from start to finish. This was not observed once but occasionally all throughout the quarter. Hence, it strengthens the researcher's belief that despite other teachers being successful in their strategic use of questions, planning is still necessary especially with the questions they will deploy during class and when they will use it. There should also be a consistency in the way teachers ask questions in class and not just totally rely on lecture-type traditional classes.

On the third theme, teachers are well aware of the expectation they have with the students' responses whenever they ask questions. It was seen that teachers were able to anticipate that whenever they ask a low-level question like asking to recall, define, or enumerate certain topic about the lesson, they expect that students will answer what they remember, a definition of the word, or vaguely what can be listed down from what retained from last meeting's discussion. Moreover, they also expect that if they ask high level questions like asking them to apply, analyze, evaluate, or create, they know that students will come through and share their views, analyze materials given, assess the quality of their work, or transcend and create a meaningful output. But with this expectation comes anticipated answers that they do not want to transpire during their classes. They acknowledge 
the existence of students' responses that do not match the questions they ask. Teachers know that there are students who will be challenged with the questions they give. With this in mind, the researcher sees the need for transcendence over this acknowledgement. Both anticipated responses from the students calls for a response from the teachers as well. In the part of those who are expected to answer the questions given, the challenge still exists for the teachers to maintain or improve that level of thinking because developing critical thinking mindset is a long and continuous process. On the other hand, intervention is much more needed to the students who cannot answer or give the most fitting answer to the questions asked.

The fourth theme also showcases the side of the students' observed difference in their responses when asked lower and higher questions. It was seen that the Grade 12 students were able to recognize the answers that they know was born from critical analysis and investigation, and which among those are just bluntly from what they remember or understood from the lesson. These answers to the remembering and understanding level questions are not just made to respond to them. Students admit that there are several barriers that hinder them in answering better than what was given. They mentioned that there are some teachers who practice both extremes of problematic questioning skills in their classes. There are some who do not ask questions at all and there are some who shows irritability when asking questions or that they use vocabulary that cannot be understood by the majority. With this, the researcher was able to it is the responsibility of the teacher to find the importance and vitality of planning strategies on how to incorporate questions within the lesson that follows a reasonable trajectory of complexity so that all students can have equal opportunities to be guided slowly within the lesson. Using simple ideas in the beginning and building it up through higher levels of questionings is one contribution that teachers can do to address this problem.

This premise was further strengthened by the fifth theme wherein the teachers observed the changes in the students' responses when they transition to higher levels of questions. Based from the discussions above, it supports the teachers' realization that there are students who are together with them in also levelling up with the quality of answers they give. From the teachers' responses, they have seen those students who answer with their own view points, together with well explained thoughts and arguments, backed up by data and evidences. With this also comes those who remains in the level where they remain stagnant to low level questions of remembering and understanding. There are students who really do not answer because they do not know what to answer and this has been clearly shared by the teachers. With this in mind, despite teachers saying they do follow-up questions or that they do not leave the students until they answer, these are harsh methods that can deeply hinder learning which is completely in contrast to why do these strategies. The researcher suggests progressive and alternative solutions to students with stagnant responses. It is obvious that waiting for them to instantaneously come up with an answer they know nothing about in the beginning is not the way to aid them. Follow up questions can still be the solution to this but there should be recalibration of the way's teachers create them. Though most follow up questions arise in the spur of the moment, teachers should be given the proper training especially that these situations are completely regular in a classroom.

The students' seen changes in their own answer, as the sixth theme identified, also reveals the same subordinate themes where they either can answer these high-level questions or they cannot. The students were able to notice the abrupt change in teachers' level of questions thus the unpreparedness that they experience. The frustrations that were seen during their interview was proof that they really want to answer but the usual discourse of discussion and questioning hinders to do so. Other than this, they are also blocked with uncontrollable mishaps like internet connection problems, failures of their devices, and all-in-all the new set up that the online class entails. That is why it is the belief of the researcher that teachers have the opportunity to adjust, improve, develop the things that they have control of like the way they formulate and ask these questions. With the empirical findings that this study was able to extract, and with the observations that the teachers have seen having to be the same with what their students notice, there should be corrective actions that follow to both the part of the teacher and the student.

The rest of the themes that emerged in the study were basically the strategies that both the teachers and the 
students had developed to improve one common skill and that is the students' critical thinking skills. The critical thinking skills were identified as the evaluation and recognition of assumptions, the analysis of arguments, deduction, and the drawing of information and inferences. This follows common strategies from both the teachers and students. Majority of which entails the immersion of students to sessions and classes filled with well-constructed, rich, and high-level questions with a balanced inclusion of the low-level questions as basis. Both the students and the teachers recognize the importance of dedicating the right amount of time for clarifications and deepening of lessons with the students through a dialogue of questions and answers. Moreover, both groups were able to see the significance of activities that are constructed based on the identified critical thinking skills. With the difference between English subjects, like research and creative writing, the subject teachers have command over the content of the questions. Likewise, they also have freedom to create activities that will cater to these skills now that this study can guide them through it. Other than this, they also see the role of using different resources like books, journals, other researches, and the like, in developing students' critical thinking skills. Relevant resources allow the students to be well-acquainted with the most updated trends and discussion which can add more validity and be used as evidence to what they encounter first hand. Also, it consistently trains them to judge the relevance of the materials viewed and seek to find connection to what is being asked. Other strategies mentioned include note-taking, making reviewers, using signal words, and using the other critical thinking skills to also develop other thinking skills as well. With the discussions made, the researcher was able to realize that the answers of both the teachers and the students were made through knowing the meaning behind the questions of the interview, and then was followed by identifying what is being practiced at the moment that can fit the critical thinking skill being asked. This means that they were not able to fully understand the impact of how teachers ask and how students think if not asked to do so. Furthermore, they were not able to create means on how to develop critical thinking among students if not asked what contributions do, they think is most effective. That is why the researcher was able to realize that there is a lack of training for teachers' questioning and unguided interventions for students to develop their critical thinking skills.

\subsection{On the Recommendations}

First is for the Grade 12 Senior High School Students. Critical thinking skills are essential to every experience they will have in the present and in the future. They should be able to utilize all of these skills when the moment asks for it. They are advised to question the validity of the materials given, instinctively gather other evidence to support them, and connect this new-found information to the standing premise to make a sound conclusion. They are also advised to improve and develop these skills using the identified strategies by the participants of the study whichever will fit their needs in a given subject. Furthermore, they are advised to continue to relentlessly pursue any means to avoid being complacent and stagnant about the skills they think they already have.

The second is for the Grade 12 Senior High School English Teachers. It is the responsibility of the educators to provide quality education despite the circumstances brought by this pandemic. In the area of the level of questions asked by the teachers, it is advised that teachers find time to plan for the content of these questions, build a consistent habit of using varied questions, and uphold the quality of these queries no matter how abrupt the flow of the dialogue in classes is. They are advised to not only plan but also execute them vigorously during their classes and value the feedback that may arise from the assessment brought by those who will benefit from the improvement of their questioning.

With this, the third one is for the head teachers, teachers-in-charge, or subject area coordinators. The head teachers are responsible for coordinating with the other subject teachers, in this case the Communication Arts English teachers in Grade 12, in the different tasks needed to be done in teaching. Furthermore, head teachers are the first in line to ensure quality instruction and other facets of education. That is why it is recommended that the findings of this study may be used as points for improvement and basis for affirmation of their performance in their questioning ability which can be an added indicator in the school's Performance Management System (PMS). 
Grade 12 English teachers' questioning in developing students' critical thinking skills: A two-phase model

The fourth one is the School Administrators. The School Heads function as the overhead committee and core council to any concerns, and decisions about academics and instruction. With this, it is advised that they provide programs and interventions to keep in check the ordinary responsibilities of the teachers that could deteriorate in quality: one of which is the questioning ability of teachers. With this, it is also advised that the same be done with the students' critical thinking ability which might also be left unimpeded since there are prevailing notions that this can easily be improved by just attending classes.

The fifth one is the researcher. In the pursuit of developing and improving the same research, it is recommended to pursue a wider range when it comes to the population specifically, it is advised to go to other Canossian Schools in CALABARZON or even to public schools in the division. Furthermore, the improvement of the instrument is highly recommended, especially in retrospect to the internal and external validity of the assessment tool.

Finally, the fifth one is the future researchers. They must give more focus to the improvement of the assessments given to the teachers and head teachers in measuring their levels of questioning and the test given to the Grade 12 students to measure their critical thinking skills. They are also advised to do more comprehensive and wider scope of the research particularly branching out to the lower levels in Senior and Junior High School to other subject areas, or to the other branches of Canossa School, and to other public and non-sectarian schools. Finally, they are advised to do more in-depth description of the lived experiences of the participants.

\section{References}

Aggarwal, S. (2020, July 27). 10 games that help kids think critically. Kid Pillar. https://kidpillar.com/games-kids-think-critically-critical-thinking/

Amel, N., \& Davoudi, M. (2015). A systematic review of research on questioning as a high-level cognitive strategy. Education Resource Information Center. https://eric.ed.gov/?id=EJ1078735

Amilia, K., \& Fitriani, S. (2017). Frequency of questions in an EFL conversation class. Education Resource Information Center. file:///C:/Users/Sarah\%20Angela/Downloads/9208-21805-1-SM.pdf

Anaraki, S. S., Zareian, G., Khodaee, M., Perez, A., \& Taber, K. (2015, May 2). What will be the research paradigm for mixed method research? Research Gate. https://www.researchgate.net/post/What_will_be_the_research_paradigm_for_mixed_method_research

Anderson, \& Krathwohl. (1956). Bloom's revised taxonomy. Colorado College. https://www.coloradocollege.edu/other/assessment/how-to-assess-learning/learning-outcomes/blooms-r evised-taxonomy.html

AssessmentDay. (n.d.). Watson Glaser critical thinking appraisal. AssessmentDay. https://www.assessmentday.co.uk/watson-glaser-critical-thinking.htm

Assumptions. (n.d.). Assumptions. Louisville Library. https://library.louisville.edu/ekstrom/criticalthinking/assumptions

Baker, A. (2016). Critical thinking skills | College success. Lumen Learning. https://courses.lumenlearning.com/suny-collegesuccess-lumen1/chapter/critical-thinking-skills/

Barshay, J. (2019). Scientific research on how to teach critical thinking contradicts education trends. Hechinger Report.

https://hechingerreport.org/scientific-research-on-how-to-teach-critical-thinking-contradicts-education-t rends/

Bello, P. A. (2013). The art of questioning of the faculty in the college of teacher education in the university of Northern Philippines. University of Northern Philippines. http://journal.unp.edu.ph/index.php/unprj/article/view/12

Bataineh, R. F., \& Zghoul, L. H. (2006). Jordanian TEFL graduate students' use of critical thinking skills (as measured by the Cornell Critical Thinking Test, Level Z). International Journal of Bilingual Education and Bilingualism, 9(1), 33-50. https://doi.org/10.1080/13670050608668629

Belyh, A. (2019, September 25). Learn why employers value deductive reasoning, and how you can show it. 
Cleverism.

https://www.cleverism.com/learn-why-employers-value-deductive-reasoning-and-how-you-can-show-it /\#:\%7E:text=Fortunately\%2C\%20anyone\%20can\%20improve\%20their,well\%20as\%20by\%20solving $\% 20$ puzzles

Bill, R., Yang, Y. T., \& Newbie, T. (2010). Using Socratic questioning to promote critical thinking skills through asynchronous discussion forums in distance learning environments. https://www.tandfonline.com/doi/abs/10.1207/s15389286ajde1903_4

Bryan, S. (2018). Signal phrases and verbs. signal phrases and verbs, 11(3), 1-3. Blinn College. https://www.blinn.edu/writing-centers/pdfs/Signal-Verbs-and-Phrases.pdf

Buoygues, H. L. (2019, May 23). 3 simple habits to improve your critical thinking. Harvard Business Review. https://hbr.org/2019/05/3-simple-habits-to-improve-your-critical-thinking

Cazares, M. (2016). Critical thinking by Edward Glaser. Bartleby.

https://www.bartleby.com/essay/Critical-Thinking-By-Edward-Glaser-FKL3Y29CF9LX

Chee, J. (2015). Pearson's product-moment correlation: Sample analysis. Research Gate. https://www.researchgate.net/publication/277324930_Pearson's_Product-Moment_Correlation_Sample Analysis

Cheung, D. (2017). The key factors affecting students' individual interest in school science lessons. International Journal of Science Education, 40(1), 1-23. https://doi.org/10.1080/09500693.2017.1362711

Chiou, G., \& Hu, H. (2012). The types, frequency and quality of elementary pupil's questions in an online environment. Education Resource Information Center. https://files.eric.ed.gov/fulltext/EJ989286.pdf

Chikiwa, C., \& Schafer, M. (2018). Promoting critical thinking in multilingual mathematics through questioning. Euroasia Journal of Mathematics, Science and Technology Education.

https://www.ejmste.com/download/promoting-critical-thinking-in-multilingual-mathematics-classes-thr ough-questioning-5523.pdf

Clark, \& Chopeta. (2004). Bloom's Revised Taxonomy: Cognitive processes and levels of knowledge matrix. Blogspot. http://bdld.blogspot.com/2014/06/blooms-revised-taxonomy-cognitive.html

Clandfield, L. (2020). One-to-one methodology: Advantages and disadvantages for teachers. One Stop English. https://www.onestopenglish.com/support-for-business-teachers/one-to-one-methodology-advantages-an d-disadvantages-for-teachers/144656.article

Granite State College. (n.d.). Ch. 9 Questioning - Instructional methods, strategies and technologies to meet the needs of all learners. Granite Pressbooks Publishing, from https://granite.pressbooks.pub/teachingdiverselearners/chapter/questioning-2/

Cooper, B. (2016, April 13). What are the 21st Century skills needed inside the classroom? Simple Kto12, from https://www.simplek12.com/learning-theories-strategies/4cs-21st-century-skills/

Cotton, C. (n.d.). Classroom questioning. Education North West. https://educationnorthwest.org/sites/default/files/resources/classroom-questioning-508.pdf

Cottrell, S. (2017). Critical thinking skills: Effective analysis, argument and reflection.

Crockett, L. (2019). 12 strong strategies for effectively teaching critical thinking skills. Global Digital Citizen. https://globaldigitalcitizen.org/12-strategies-teaching-critical-thinking-skills/amp

Crossman, A. (2020, February 2). What is qualitative research? Thought Co. https://www.thoughtco.com/qualitative-research-methods-3026555

Cumhur, F., \& Matteson, S.M. (2017). Mathematics and science teacher candidates' beliefs of developing questioning skills in Turkey. Education Resource Information Center. https://eric.ed.gov/?id=EJ1207292

Deakin University. (n.d.). Reflective learning. Deakin University. https://www.deakin.edu.au/students/studying/study-support/academic-skills/reflective-learning

Doyle, A. (2019). Why employers value critical thinking. The Balance Careers. https://www.thebalancecareers.com/critical-thinking-definition-with-examples-2063745

Dumteeb. (2009, July 1). Teachers' questioning techniques and students' critical thinking skills: English language classroom in the Thai context. Share OK. https://shareok.org/handle/11244/7214

Duoblys, G. (2019, June 22). Teaching deductive reasoning in the classroom - George Duoblys. Medium. 
Grade 12 English teachers' questioning in developing students' critical thinking skills: A two-phase model https://medium.com/@ghduoblys/9-teaching-deductive-reasoning-in-the-classroom-eb470b3eea2e

Elfrida, et al. (2019). Students' responses toward teachers' questions in senior high school 8 Bengkulu. https://jurnal.unigal.ac.id/index.php/jall/inde

Ennis, R. H. (2011, May). The nature of critical thinking: an outline of critical thinking dispositions and abilities. Illinois University.

https://education.illinois.edu/docs/default-source/faculty-documents/robert-ennis/thenatureofcriticalthin king 51711_000.pdf

Erstad, W. (2018). 6 critical thinking skills you need to master now. Rasmussen University Orlando. https://www.rasmussen.edu/student-experience/college-life/critical-thinking-skills-to-master-now/indee d.com/career-advice/career-development/critical-thinking-skills/

Feldmann, C. (2014). Sampling and relevance. Critical Thinking Organization. https://www.criticalthinking.org/pages/a-brief-history-of-the-idea-of-critical-thinking/408

Ferlazzo, L. (2018, November 21). Response: Students as teachers in the classroom. EdWeek. https://blogs.edweek.org/teachers/classroom_qa_with_larry_ferlazzo/2018/11/response_students_as_tea chers_in the classroom.html

Fink, K. (2020, May 5). 5 critical thinking activities that get students up and moving. We are teachers. https://www.weareteachers.com/critical-thinking-activities/

Foster, H. L. (2017). Critical thinking and its impact. Asia Pacific International University. http://isc2017.apiu.edu/conference-papers/aiu/Foster.Critical.thinking.curriculum.pdf

Fries-Gaither, J. (2008). Questioning techniques: Research-based strategies for teachers. Beyond Penguins. https://beyondpenguins.ehe.osu.edu/issue/energy-and-the-polar-environment/questioning-techniques-res earch-based-strategies-for-teachers

Ganti, A. (2020, March 10). Weighted average definition. Investopedia. https://www.investopedia.com/terms/w/weightedaverage.asp

Garret. (1987). The Socratic method. https://webcache.googleusercontent.com/search?q=cache:WvHgmwu5X_IJ:https://www.law.uchicago.e $\mathrm{du} /$ socratic-method $+\& \mathrm{~cd}=18 \& \mathrm{hl}=\mathrm{en} \& \mathrm{ct}=\mathrm{clnk} \& \mathrm{gl}=\mathrm{ph}$

Girgis, H. (2020). Classroom activities: Definition, groups, evaluation, rewards, benefits, and results. http://www.bchmsg.yolasite.com/classroom-activities.php

Glaser. (1941). Defining critical thinking. https://www.criticalthinking.org/pages/defining-critical-thinking/766

Griffen, K., \& Ryan, S. (2016, June 27). Top 5 active student responding strategies. https://spedsheets.com/index.php/2018/06/20/top-5-active-student-responding-strategies/

Haber, J. (2020). It's time to get serious about teaching critical thinking. Inside Higher Ed. https://www.insidehighered.com/views/2020/03/02/teaching-students-think-criticallyopinion

Habibah, S., Setyowati, R., \& Mustika, M. (2018). Improving critical thinking skills of students through the development of teaching materials. https://doi.org/10.2991/icss-18.2018.50

Hall, G. (2016, September 17). The importance of questioning. https://garyhall.org.uk/importance-of-questioning.html

Hall, C., Vaughn, S., Barnes, M. A., \& Stewart, A. A. (2019). The effects of inference instruction on the reading comprehension of English learners with reading comprehension difficulties. Remedial and Special Education, 12. https://doi.org/10.1177/0741932518824983

Hitchcock, D. (2018, July 21). Critical thinking. https://plato.stanford.edu/entries/critical-thinking/

Hodge, K. A., \& Walsh, R. L. (2016). Are we asking the right questions? An analysis research on the effects of teachers' questioning on children's language during shared book reading with young children. https://doi.org/10.1177/1468798416659124

Hurst, K. (2017, December 21). How to develop critical thinking skills: 5 strategies. The Law of Attraction. https://www.thelawofattraction.com/develop-critical-thinking-skills/

Johnson, B. R., Onwuegbuize, A., \& Turner, L. (2007, April 1). Toward a definition of mixed methods research. https://doi.org/10.1177/1558689806298224

Joseph, S. (2018). Questions teachers ask: An explanatory study of teachers' approach to questioning in the 
Gacutan, S. A. B., \& Recillo, M. L. B.

primary and secondary classroom. Journal of Education and Social Policy. http://jespnet.com/journals/Vol_5_No_1_March_2018/9.pdf

Joseph, M. (2019, November 19). Strategies to increase critical thinking skills in students. https://www.teachbetter.com/blog/strategies-to-increase-critical-thinking-skills-in-students/

Kiss, T. (2018). Investigating teacher questions within the framework of knowledge building pedagogy. Education Resource Information Center. https://files.eric.ed.gov/fulltext/EJ1151080.pdf

Komur, H., \& Seker, S. (2008). The relationship between critical thinking skills and in-class questioning behaviours of English language teaching students. https://doi.org/10.1080/02619760802420784

LEARN090. (2017, December 1). Questioning as feedback [Video file]. YouTube. https://www.youtube.com/watch?v=VFcO2SUj4jc\&feature=youtu.be

Leech, N. (2008). Mixed method research. https://www.deakin.edu.au/_data/assets/pdf_file/0020/681023/Dr-r-cameron_mixed-methodology.pdf

Marija, S. (2016). Factors that affect classroom participation. https://scholarworks.rit.edu/cgi/viewcontent.cgi?article=10526\&context=theses\#: :text=Numerous $\% 20$ studies $\% 20$ have $\% 20$ been $\% 20$ conducted,preparation $\% 20$ for $\% 20$ class $\% 2 \mathrm{C} \% 20$ and $\% 20$ confidence

Marquez, \& P. L. (2017, September 30). Critical thinking in Philippine education: What we have and what we need. Education Resource Information Center. https://eric.ed.gov/?id=EJ1156246

Marzano, R. (2017). The new art and science of teaching. Solution Tree Press. http://www.ascd.org/Publications/Books/Overview/The-New-Art-and-Science-of-Teaching.aspx

Mc Kay, et al. (2016). Learning how to find, evaluate, and use resources to explore a topic in depth. https://www.ideaedu.org/idea-notes-on-learning/learning-how-to-find-evaluate-and-use-resources-to-ex plore-a-topic-in-depth/

Mogato, A. (2020, February 4). How to develop students' critical thinking skills? The Educator Online. https://www.theeducatoronline.com/k12/news/how-to-develop-students-critical-thinking-skills/269821

Mukaka, M. M. (2012, September). Statistics corner: A guide to appropriate use of correlation coefficient in medical research. National Center for Biotechnology Information. Retrieved from https://www.ncbi.nlm.nih.gov/pmc/articles/PMC3576830/

Musingafi, M. (2014). Students and questioning: A review of the role played by students generated questions in the teaching and learning process.

https://www.researchgate.net/publication/266642652_Students_and_Questioning_A_Review_of_the_R ole_Played_By_Students_Generated_Questions_in_the_Teaching_and_Learning_Process

Nappi, J. S. (2018). The importance of questioning in developing critical thinking skills. The Delta Kappa Gamma Bulletin: International Journal for Professional Educators.

https://cpb-us-e1.wpmucdn.com/cobblearning.net/dist/6/3101/files/2018/05/The-Importance-of-Questio ning-2aqkc5j.pdf

Niel, R. A., \& Sumayao, E. D. (2016). The art of questioning of science teachers in developing the students' higher order thinking skills at Naval State University, Naval, Biliran, Philippines. CORE. https://core.ac.uk/download/pdf/144762313.pdf

Nuhoğlu, H. (2020). The effect of deduction and induction methods used in modelling current environmental issues with system dynamics approach in science education. Participatory Educational Research, 7(1), 111-126. https://doi.org/10.17275/per.20.7.7.1

Patterson, R. (2019). 7 ways to improve your critical thinking skills. https://collegeinfogeek.com/improve-critical-thinking-skills/

Persaud, C. (2020, September 14). Bloom's taxonomy: The ultimate guide. TopHat. https://tophat.com/blog/blooms-taxonomy/

Ramos, J. J. (2020, September). Critical thinking skills among senior high school students and its effect in their academic performance. International Journal Social Sciences and Humanities. https://ijssh.ielas.org/index.php/ijssh/article/view/69

Ranadive, A. (2018, August 25). 5 questions to improve your critical thinking skills [Part 1]. Medium. https://medium.com/@ameet/5-questions-to-improve-your-critical-thinking-skills-part-1-283cf3d1506c

110 Consortia Academia Publishing (A partner of Network of Professional Researchers and Educators) 
Grade 12 English teachers' questioning in developing students' critical thinking skills: A two-phase model

Richards, J. C. (2016, September 13). Advantages and disadvantages of using instructional materials in teaching ESL. Professor Jack Richards.

https://www.professorjackrichards.com/advantages-and-disadvantages-of-using-instructional-materialsin-teaching-esl/

Rusbult, C. (2018). Critical thinking skills in education and life. Education for practical critical thinking skills to use in everyday life. https://www.asa3.org/ASA/education/think/critical.htm

Sadker, D. (2020). Classroom questions - Types of questions, feedback, effective questioning practices. State University. https://education.stateuniversity.com/pages/1836/Classroom-Questions.html

Sano, M. (2014). Critical thinking skills and teachers' questioning behavior in a Japanese University EFL context. SOKA University. http://daigakuin.soka.ac.jp/content/tesol/files/2014_RT_Sano.pdf

Santos, L. F. (2017, July 31). The role of critical thinking in science education. Education Resource Information Center from https://eric.ed.gov/?id=ED575667

Schoonenboom, J., \& Johnson, R. B. (2017). How to construct a mixed methods design. https://www.ncbi.nlm.nih.gov/pmc/articles/PMC5602001/

Shabatura, J. (2018). Using Bloom's taxonomy to write effective learning objectives. University of Arkansas. https://tips.uark.edu/using-blooms-taxonomy/

Singh, A. (2020, July 20). Develop critical thinking skills in students. The Asian School. https://www.theasianschool.net/blog/develop-critical-thinking-skills-in-students/

Spedell Reading Strategies. (2015). Making inferences. https://spedellreadingstrategies.weebly.com/making-inferences.html

Stauffer, B. (2020). What are the 4 C's of 21 st century skills? Department of Agriculture, Economics, Sociology, and Education. https://www.aeseducation.com/blog/four-cs-21st-century-skills

Stevens-Fulbrook, P. (2020, January 27). GUIDE: The 11 best types of questions in the classroom. Teacher of Science. https://teacherofsci.com/types-of-questions-in-the-classroom/

Smartsclub. (n.d.). Strategies to develop critical thinking skills. Smarts Club. https://smartsclub.net/strategies-to-develop-critical-thinking-skills-from-an-early-age/

Su, H. F., Ricci, F. A., \& Mnatsakanian, M. (2016). Mathematical teaching strategies: Pathways to critical thinking and metacognition. Journal of Research in Education and Science. https://eric.ed.gov/?id=EJ1105157

Sulaiman, M. (2020). Application of teachers' knowledge of Socratic questioning in developing EFL critical thinking skills among Omani post-basic learners. Arab World English Journal. https://www.researchgate.net/publication/343792192_Application_of_Teachers'_Knowledge_of_Socrati c_Questioning_in_Developing_EFL_Critical_Thinking_Skills_among_Omani_Post-Basic_Learners

Sunggingwati, D. (2013). Teachers' questioning in reading lessons: A case study in Indonesia. Research Gate. https://www.researchgate.net/publication/289008398_Teachers'_questioning_in_reading_lessons_A_cas e_study_in_Indonesia

Teo, T. W., \& Goh, W. P. J. (2019). Assessing lower track students' learning in science inference skills in Singapore. Asia-Pacific Science Education. Springer Open. https://doi.org/10.1186/s41029-019-0033-z

Thakur, V. (2020, April 3). 5 major things students expect from their teachers - RUBEX Blog. Medium. https://medium.com/rubex-blog/5-major-things-students-expect-from-their-teachers-3a5a5efab011

The Socratic Method. (n.d.). The Socratic method. The University of Chicago. https://www.law.uchicago.edu/socratic-method

Tomaszewski, M. (2020). Critical thinking skills: Definition, examples \& how to improve. Zety. https://zety.com/blog/critical-thinking-skills

What are sampling method. (n.d.). Sampling method review. Khan Academy. https://www.khanacademy.org/math/statistics-probability/designing-studies/sampling-methods-stats/a/sa mpling-methods-review?utm_account=Grant\&utm_campaignname=Grant_Math_Dynamic\&gclid=Cj0 KCQjwpfHzBRCiARIsAHHzyZpQ3glDvg0Sz7s_ N_haWkmAln4sNFHyEPvS9uSDS9qOFQ5GpBg YOkaAsyKEALw_wcB

Uribe-Enciso, O. L., Uribe-Enciso, D. S., \& Vargas-Daza, M. D. P. (2017). Critical thinking and its importance 
Gacutan, S. A. B., \& Recillo, M. L. B.

in education: Some reflections. https://doi.org/10.16925/ra.v19i34.2144

UofL Libraries. (n.d.). Critical thinking and academic research: Assumptions. University of Louisville. https://library.louisville.edu/ekstrom/criticalthinking/assumptions

Vale, R. D. (2013, March). The value of asking questions. National Center for Biotechnology Information. https://www.ncbi.nlm.nih.gov/pmc/articles/PMC3596240/

Veenstra, J. Q. (2017). What is "frequency" in statistics?. Quora. https://www.quora.com/What-is-"frequency"-in-statistics

Vecaldo, R. (2019). Epistemological beliefs, academic performance and teaching competence of pre-service teachers. Asia-pacific Journal for Multidisciplinary Research. http://www.apjmr.com/wp-content/uploads/2017/04/APJMR-2017.5.2.13.pdf

Watson Glaser critical thinking test is designed to assess. (2020). Watson Glaser Critical Thinking Test: Best Examples \& Tips. WikiJob. https://www.wikijob.co.uk/content/aptitude-tests/test-types/watson-glaser

Weimer, M. (2018, October 22). Five types of student questions and sample responses. Teaching Professor. https://www.teachingprofessor.com/topics/teaching-strategies/participation-discussion/five-types-studen t-questions-sample-responses/

Westendorf, E. (2018). The importance of the 5 practices: Anticipation. LearnZilion. https://blog.learnzillion.com/blog/the-importance-of-the-5-practices-anticipation\#:\%7E:text=Why\%20is \%20anticipating\%20important $\% 3 \mathrm{~F}$,to\%20the\%20lesson $\% 27 \mathrm{~s} \% 20$ learning $\% 20$ target

Whenham, T. (2020, April 16). 9 benefits of active learning (and why your college should try it). Nureva. https://www.nureva.com/blog/education/9-benefits-of-active-learning-and-why-your-college-should-try -it

Wilson, M. (2018). Critical thinking: Skills hub. University of Sussex. http://www.sussex.ac.uk/skillshub/?id=277\#:\%7E:text=In\%20fact\%2C\%20it\%20is\%20essential,makes $\% 20$ sense \%20and\%20is\%20accurate

Your Therapy Source. (2019, July 25). What is prompting? Your Therapy Source. https://www.yourtherapysource.com/blog1/2019/07/25/what-is-prompting/

Yousaf, A., \& Akhter, M. (2018). Evaluating information skill in secondary school students as a contributor in competency based education. Bulletin of Education and Research. Education Resource Information Center. https://files.eric.ed.gov/fulltext/EJ1209754.pdf

Zulmaulida, R. (2018). Watson-Glaser's Critical Thinking Skills. IOP Publishing. 